Uluslararası Sosyal Bilgilerde Yeni Yaklaşımlar Dergisi, 2021, 5(1), 305-321

International Journal of New Approaches in Social Studies, 2021, 5(1), 305-321

\title{
Osmanlı Devleti'nde Esnafın Genel Özellikleri ve XVIII. Yüzyıl Konya Esnafiyla İlgili Bazı Tespitler
}

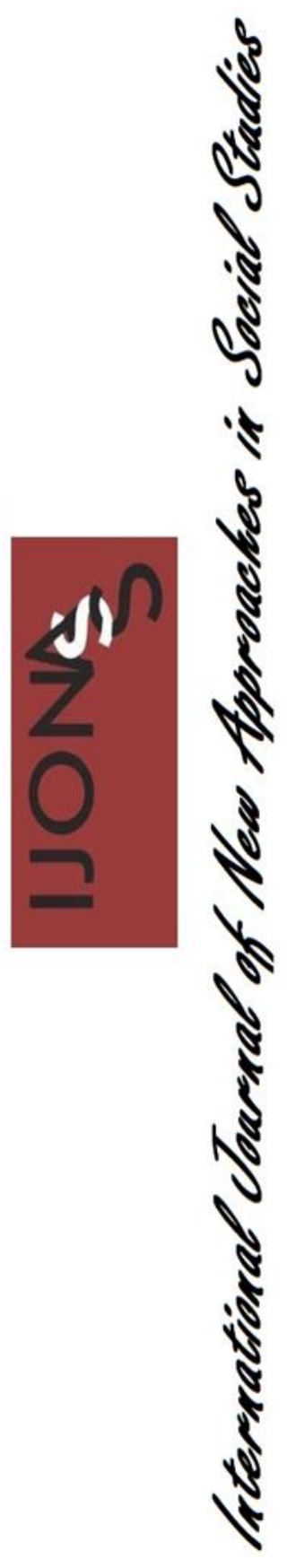

\author{
Zafer YILDIRIM ${ }^{1 *}$ (D)
}

Gönderilme Tarihi: 02 Haziran 2021 Kabul Tarihi: 28 Haziran 2021

DOI: $10.38015 /$ sbyy. 947262

\begin{abstract}
$\ddot{O}_{z:}$
Osmanlı Devleti'nde esnaf teşkilatı, son derece düzenli ve disiplinli bir yapıya sahipti. Bu durum birçok belgeyle de açıkça ortaya konulabilir. Zaman zaman ahilik, lonca, gedik gibi kavramlar kullanılsa da genel olarak yapının muhafaza edildiği görülmektedir. Yerel anlamda kadı'nın başkanlı̆̆ında bir yönetim heyeti bulunur ve bunlar esnafla ilgili pek çok konuda kararlar alırlardı. Esnafin yetişme tarzı, çıraklıktan kalfalı̆̆a ve sonunda da ustalı̆̆a yükselme durumu da oldukça sıkı bir denetim ve eğitim sürecine tabiydi. Bu denetim süreci, esnafin fiyat politikasinda da narh sistemi olarak karşımıza çıkmaktadır. Esnafin Osmanlı seferlerine katkıda bulunduğu, orducu esnafi adı altında aktif görevler üstlendiği de görülmektedir. Kadim bir Türk-İslam şehri olan Konya, Osmanlı hâkimiyetine girdiği XV. Yüzylldan itibaren Osmanlı kültürünün en önemli merkezlerinden biri haline gelmiştir. Konya'da esnaf teşkilatı, bu kültürün izlerini taşımakta ve Osmanlı Devleti'nin genel yapısına uygun bir tablo oluşturmaktaydı. XVIII. yüzyılda da bu durumun bazı istisnalar dışında korunduğu anlaşılmaktadır. Özellikle şer'iyye sicilleri bu hususla ilgili birçok belge içermektedir. Konya esnafi XVIII. yüzyılda teşkilat yapısını muhafaza etmiş, narh sistemini uygulamış, sefer zamanları orduya katkılarda bulunmuş, görev yaptığı çarşı ve dükkânlarla da sosyal hayatta önemli bir yer edinmiştir. Bu çalışmada öncelikle Osmanlı esnafinın genel özellikleri hakkında bilgiler verilecektir. Esnaf teşkilatının yöneticileri ve organizasyonu örneklerle ortaya koyulacaktır. Sonrasında ise Konya şehrinde XVIII. yüzyılda esnafın durumu, yönetim şekli belgeler ışı̆̆ında sunulmaya çalışılacaktır.
\end{abstract}

Anahtar Kelimeler: Osmanlı Devleti, esnaf, Konya, ticaret.

\begin{abstract}
:
The organization of the tradesmen in the Ottoman State had a highly organized and disciplined structure. This event can be clearly demonstrated by many documents. Although the concepts such as "ahilik", "lonca" and "gedik" are used from time to time, the structure is generally preserved. In the local sense, there was a governing committee headed by the "kadl" and they took decisions on many issues related to tradesmen. Tradesman's upbringing, apprenticeship to squad and eventually mastery was also subject to a very strict supervision and training process. This audit process is seen in the price policy of the tradesmen as "narh" system. It is also seen that tradesmen contributed to Ottoman expeditions and undertook active duties under the name of "orducu" tradesmen. Konya, an ancient Turkish-Islamic city, has become one of the most important centers of Ottoman culture since the fifteenth century when it entered Ottoman rule. In Konya, the tradesmen organization carried the traces of this culture and formed a picture in accordance with the general structure of the Ottoman Empire. In the eighteenth century it is understood that this situation is preserved with
\end{abstract}

\footnotetext{
${ }^{1}$ Konya Necmettin Erbakan Üniversitesi, Türkiye, ORCID ID: 0000-0002-6996-2609

*SorumluYazar (Corresponding Author): zaferyildirim1299@hotmail.com
} 
some exceptions. Especially the kadi registers contain a lot of documents about this issue. Konya tradesmen maintained the organizational structure in the eighteenth century, applied the system of narh, contributed to the army in the expedition times, and took an important place in social life with its bazaar and shops. In this study, firstly, information about the general characteristics of the Ottoman tradesmen will be given. The managers and organization of the tradesmen organization will be presented with examples. Afterwards, in the city of Konya, in the 19th century, the situation of the tradesmen and the way of administration will be tried to be presented in the light of documents.

Keywords: Ottoman State, tradesmen, Konya, commercial.

\section{GíRiş}

Genel hatlarıyla belirtmek gerekirse esnaf, şehir ve kasabalarda mal ve hizmet üretimi ile ilişkili herhangi bir iş kolunun belirli bir alanında uzmanlaşmış olarak çalışanların meydana getirdiği mesleki örgütlenmeler olarak tanımlanabilir. Burada uzmanlaşılan alandan kastedilen oldukça dar ve sınırlı zümreler halinde, bir malın hammaddeden başlayarak geçirdiği üretim aşamalarından her biri olarak düşünülmelidir. Yani bu uzmanlaşma ve farklılaşan örgütlenme yapısı bir ağacın dalları gibi ayrıntılı bir tablo oluşturur (Genç, 2000, s. 293). Esnaf toplulukları için zaman içerisinde değişik isimler kullanılmıştır. Bunları şöyle sıralamak mümkündür: İlk olarak geçinmeye esas meslek anlamına gelen ve Arapça bir kelime olan hırfeti ( حرفت ) esas alan isimlendirmeler bulunur ki bunlar; esnaf-1 hirfet, erbab-1 hirfet, ehl-i hırfet, ashab-1 hırfet ve bunların çoğulu olan esnaf-1 hıref, erbab-1 hıref, ehl-i hıref, ashab-1 hireftir. İkinci olarak da esnaf-1 sanat, erbab-1 sanat, ehl-i sanat, ashab-1 sanat gibi tabirlerle bunların çoğullarıdır. Osmanlı Devleti zamanında özellikle esnaf tabirinin daha fazla kullanıldığ1 görülmektedir (Ergin, 1995, s. 487). Bununla birlikte ehl-i hırfet ve ehl-i sanat tabirleri, çeşitli mesleklere mensup olanlar için sıklıkla kullanılmıştır (Mantran, 1990, s.327).

Toplum içerisinde üretici grupların, meşgul olduğu işe göre sınıflandırılmasıyla ortaya çıkan esnaflık, insanlık tarihi kadar eskilere dayanır. Bir Türk-İ̀slam devleti olan Osmanlı Devleti'ni oluşturan toplumdaki esnaflığın kökenleri de kendisinden önceki Türk - İslam devletlerine kadar uzanır. Buna göre her esnaf kolunun kendine has gelenekleri ve her mesleğin bir pîri vardır. Mesela Hz. Âdem çiftçilerin, Hz. İdris terzilerin, Hz. Yusuf saatçilerin, Hz. Dâvûd demirci ve zırhçıların, Hz. Lokman hekimlerin, Hz. Muhammed tâcirlerin, Selmân-1 Fârisî berberlerin, Ahilik teşkilatının kurucusu olarak kabul edilen Ahî Evran ise debbăg esnafının pîri olarak kabul edilir (Kala, 1995, s. 423). Bu durum esnaf teşekküllerinin dini mahiyetini de ortaya koymaktadır.

Osmanlı Devleti'nde esnaf cemiyetlerinin serbest rekabet prensibi yerine, karşılıklı bir kontrol ve yardımlaşma esasına dayanan, imtiyaz ve inhisar usulleriyle hareket eden yapılar olduğunu belirtmek gerekir. Yani herkesin istediği mesleği, istediği yerde ve şekilde icra etmesine müsaade edilmesi mümkün değildi (Barkan, 1984, s. 39). Bu nedenle Osmanlı esnaf örgütleri, Avrupa'daki zanaatkâr ve özellikle de tüccar loncaları seviyesinde siyasi otoritenin kontrolünden bağımsız kalamamışlardır (Berkes, 1970, s. 79).

Osmanlı Devleti'nde esnaf denilen zanaat ehli, devlete ait işyerlerinde çalışanlarla serbest olarak, yani kendi işyerlerinde çalışanlar şeklinde iki ana kısma ayrılırdı. Birinci gruptakilere yani devlette maaş karşılığı çalışanlara "ehl-i hıref-i hâssa" adı verilir ve devletin bunlar üzerinde doğrudan, esnaf teşekküllerine ve loncalara bağlı özel teşebbüsler üzerinde ise dolaylı olarak bir kontrol sistemi bulunurdu. $\mathrm{Bu}$ şekilde devlet, bütün esnaf kuruluşlarını 
hammadde temini, imalât, pazarlama, fiyat koyma ve satış aşamalarında denetim altında tutar ve ihtiyaç anında serbest meslek sahipleri de devlet hizmetine alınabilirdi. Buna genellikle savaş zamanlarında başvurulur, ordunun gıda temini, elbise, savaş malzemesi yapım ve onarımı gibi ihtiyaçlarının karşılanması amaçlanırdı. Bu şekilde, ihtiyaç sebebiyle orduya katılan ve devlete ait olan iş yerlerinde istihdam edilen esnaf sınıfina "orducu esnaf" denilirdi (Kala, 1995, s. 423). Bu grupların bazı zamanlarda seferlere nakdi ödemelerle destek oldukları da görülmektedir.

\section{Osmanlı Devleti'nde Esnafin Genel Özellikleri}

Ticari hayatın yoğun bir şekilde yaşandığı devlet sınırları içerisinde, esnafın birbirleriyle olan ilişkileri çerçevesinde, genel hukuk ve zabıta kurallarının düzeni koruması oldukça zordu. Çalışanlardan birinin alacağı karar ve tavır diğerlerine de etki edebilirdi. Bütün bu ilişkileri düzenleme ve muhtemel ihtilafları çözme işini Osmanlı Devleti'nin adalet sisteminin temel kurumu olan kadılık müessesesinin yapması en uygun olanıydı. İhtilaflı durumlar Kadı'ya ulaşmadan önce ara örgütlenmeler tarafindan da en aza indiriliyordu. İşte esnaf teşkilatı bu ara örgütlenmelerden biriydi (Genç, 2000, s. 295). Bu organizasyon hem esnafın kendi içerisindeki, hem başka esnaf gruplarıyla ilişkilerini kontrol ediyordu. Aynı zamanda devletle olan ilişkilerinde de aracılık rolü oynuyordu.

Esnaf teşkilatının zanaat ve ticareti düzenlemekte etkin bir rolü bulunmaktaydı. Bir şehirdeki esnaf örgütleri birbirleriyle temasta bulundukları gibi başka şehirdekilerle de iletişim kurmuşlardır. Bu birlikleri ayrı ayrı çalışan fakat aralarında içtimai bir birlik bulunan ihtisas birlikleri olarak nitelendirebiliriz (Tabakoğlu, 2000, s. 282-283). Bu örgütlenmenin mekân1 şehir ve kasaba merkezleriydi. Her şehirdeki örgütlenme türü nüfus miktarı ve iktisadi özelliklere göre değişiklikler göstermekle birlikte yapı itibarıyla benzer nitelikteydi. $\mathrm{Bu}$ örgütlenmeler arasında debbağ esnafı dışında bölge ve ülke çapında ilişkiler bulunsa da bu duruma çok sık rastlanmaz. Kırşehir'deki Ahi Evran Zaviyesi'nin liderliğinde zayıf bir bağ içinde bulunan debbağ esnafi hemen hemen her şehirde faaliyet gösteriyordu. Bununla birlikte İstanbul gibi büyük şehirlerde aynı esnaf örgütünün parçalara bölünerek ayrı birimler halinde teşkilatlandığ1 da görülür (Genç, 2000, s. 294). Bu durumla ilgili erken dönemlere ait belgelerde çeşitli örnekler bulunmaktadır. Örneğin 1582 tarihli bir mühimme kaydında İstanbul Kadısı'na bir hüküm gönderildiği ve yağ mumu işleyen esnafın sorun yaşadığı görülmektedir. Bunlar rikab-1 hümayuna gelerek, o zamana kadar kasapların kestikleri koyunların başlarını başçılara, derisini debbağlara ve yağını mumculara verdiklerini ifade etmişlerdir. Mum işini mumcuların işlediğini, ancak şimdi debbağların mum işine de el atmasıyla koyunların derileriyle birlikte yağlarını da aldıklarını belirtmişlerdir. Konuyla ilgili merkezden daha önce verilen emir-i hümayuna göre hareket edilmesi ve kadime muhalif iş yapılmaması emredilmiştir (BOA, DVN. MHM., 48/24). Görüleceği üzere esnafın birbiriyle olan münasebetleri merkezden gönderilen talimatlarla da düzenlenmiş bu hususta emir-i hümayunlar yayınlanmıştır. Kadime muhalif iş yapılmaması şeklinde bir emir bulunması, esnaf düzeninin oldukça eskilere dayandığını göstermektedir.

Esnaf teşkilatının temelinde çırak, kalfa, usta şeklinde ilerleyen bir düzen yer almaktaydı. Bu teşkilatın hiyerarşik yapısı ise esnaf şeyhi, kethüda, yiğitbaşı, ustabaşı, kalfa ve çırak biçimindeydi. Çıraklar zamanla kalfa ve usta olabiliyorlardı (Özkaya, 2008, s.70). Ayrıca bu yapıya şehrin yöneticilerinden olan kad1, muhtesib, nakip, ehl-i vukufu da eklemek yerinde olacaktır (Tabakoğlu, 2000, s.282). Her esnaf grubu mesleki faaliyetlerde uyulacak özel kuralları, kendi içinde kararlaştırır ve bütün unsurların ortak kararı şeklinde onay için kadıya sunardı. Kadı, teklifi şeriat, kanunlar, örf ve adetlere uygunluk açısından hızla inceledikten 
sonra Divan'a arz ederdi. Divan'da onaylanan teklif artık bağlayıcılığı olan temel bir belge haline gelirdi. Bu temel belgede; ustalık, kalfalık gibi unvanların kazanılma şartları, çıraklık ve kalfalık süreleri, çalışma şartları, üretilecek malın cinsi ve kalitesi, hammadde temini, dükkânların yeri ve sayısı gibi konular yer alırdı. Çoğunluğun iradesinde bir değişiklik olursa aynı usulle bu değişiklikler ya belgeye eklenir ya da yeni bir belge çıkarılırdı (Genç, 2000, s. 296). Esnaf birliklerinde, meslek dalındaki ustalığa ve eskiliğe dayanan bir kademeleşme söz konusu olmakla birlikte aynı dönemin batı esnafında görülen tabakalaşmadan bahsedilemez. $\mathrm{Bu}$ durumun nedeni batının sınıflı toplum yapısının yansımasıdır. Osmanlı esnaf teşkilatında ise sadece mesleki ve ahlaki üstünlükler ilerleme ve yükselmeye sebep olurdu. Bu özelliklere sahip olmayanların esnaf arasında yer edinmesi mümkün değildi (Tabakoğlu, 2000, s. 283). Şunu da belirtmek gerekir ki Avrupa'daki loncaların kapalı ve şartlara dayanan bir kişiliği vardı. Yani bunlar beledi hükmi şahsiyetler olarak görülürdü. Osmanlı hukukunda ise devlet katında, esnaf teşkilatının böyle bir özellik taşıdığı söylenemez (Berkes, 1970, s. 283).

Osmanlı Devleti sınırları içinde XVIII. yüzyılın sonlarında hizmet etmiş olan İsveç elçisi D'ohsson'un esnaf ve sanatkârlarla ilgili görüşleri ilginçtir. Onun izlenimlerine göre her meslek özel kaidelere bağlı şekilde varlığını sürdürüyordu. Bu meslekleri icra edenler ayrı teşekküller meydana getirirler ve bunlara esnaf adı verilirdi. Bunların arasındaki düzeni korumak ve onlarla ilgili nizamları kontrol etmek için devlet tarafından esnafa nezaret etmekle görevli memurlar tayin edilir ve bu memurlara kâhya adı verilir. Bu kâhyaların yiğitbaşı denilen vekilleri vardır. Bunların hepsi (İstanbul için) İstanbul kadısına bağlıdır. Bütün dükkânlar sabah şafakla birlikte açılır, gece başlarken kapanır. İki bayram zamanının dışında el sanatlarında ve ticari hayatta en küçük bir fasıla görülmez (D'ohsson, s. 144). Esnaf teşkilatıyla ilgili özel bir araştırma yapmamış olmasına rağmen D'ohsson'un bu tespitleri, esnafin o dönemlerde de düzenini muhafaza ettiğini göstermesi bakımından önemlidir.

Esnaf arasında ortaya çıkan anlaşmazlıkların çözüme bağlanması, sanat ve ticaretin kötüye gitmesine engel olunması gibi konular, esnafin ileri gelenlerinden oluşan ve kethüdanın yönetiminde bulunanlar tarafindan lonca odalarında ele alınırdı. Lonca odalarının nüfuzu hükümet tarafından bizzat korunurdu (Kazıc1, 2003, s. 125). Konuyla ilgili, 1784 tarihli bir belgede lonca meclisinden söz edilmektedir. İstanbul'da Bayezid Camii civarında ve Mahmut Paşa yakınlarında bulunan kaşıkçı ve tarakçı esnafının hasılatlarına bazı kişilerin müdahalede bulundukları belirtilen belgede bu durum üzerine iki esnaf grubunun lonca meclislerini toplayarak gerekli tedbirleri aldıkları ifade edilmektedir (BOA, AE. SABH. I, 259/17399). Görüleceği üzere esnaf grupları gerekli görülen durumlarda, hem kendi haklarını korumak hem de kadim düzeni devam ettirmek için meclis tabir edilen grup toplantıları düzenlenmekteydi.

Osmanlı Devleti'nde esnaf, disiplin açısından kendine has özelliklere sahipti. Devletin fiyatlandırma uygulaması olan narh hususunda, beşeri yanılma payı içindeki sapmalara ceza işlemi uygulanmazken, bu oran aşıldığında da çok sert tedbirlere başvurulmazdı. İkaz ve tavsiyede bulunmak en çok başvurulan yoldu. Narhtan sapmalar yüksek orana ulaşır ve tekerrür ederse, suçlu Müslümansa hapse atılır, gayrimüslimse küreğe konulurdu. $\mathrm{Bu}$ da birkaç hafta ile birkaç ay arasında fazla uzun olmayan bir süre ile sınırlandırılırdı. Burada en önemli nokta hatanın tekerrür etmesiydi (Genç, 2000, s.298-299). Narha verilen önemi anlatmaya yardımcı olacak 1818 tarihli bir belgede, Kasımpaşa'da narhtan noksan çörek satan çörekçiler kethüdası Seyyid Ömer ve yiğitbaşı Mustafa'nın Magosa Kalesi'ne sürgün edildikleri kayıtlıdır (BOA, C.BLD., 130/6478). 
Esnafın bir arada bulunduğu çarşılar toplum yaşamının önemli bir merkezini teşkil ederdi. Çarşı Osmanlı kentinde esnafın başkahramanı olduğu kent kültürü bağlamında, özel bir sentez içerisinde kültürel ifadesini bulan bir bütünü ifade ederdi. Üç farklı günde, Müslümanlar için cuma, Yahudiler için cumartesi, Hristiyanlar için pazar olmak üzere dükkânların sırayla kapanıyor olması haftayı bölümlere ayırırdı. Gün ibadet saatlerine göre ölçülür, halk çarşıda batılı uygulamalar ve batı fikirleriyle birlikte yaşamayı denerdi (Cerasi, 1999, s.116).

Hem tüketicinin işini kolaylaştırmak hem de kontrolü sağlayabilmek amacıyla aynı işi yapan ya da aynı malı satan esnaf mümkün mertebe aynı çarşı veya handa bulunurdu. Osmanlı şehirlerinde aynı mesleği icra eden esnafın bulunduğu çarşılar mahalli isimlerle anılsalar da fonksiyonları aynıydı. Özellikle Arap kentlerinde bunlara "sûk" deniliyordu (Kazıcı, 2003, s. 129). Dükkânların düzenli bir biçimde karşılıklı birer sıra halinde dizilmiş olarak bulunduğu veya ordugâh pazarlarının askerî disiplin içinde düzenlenmiş bir şekilde satış yaptıkları yani bu dükkânların gezgin satıcılara nispetle her hususta düzene konulmuş olduğu ve arasta denilen yerler de çarşı kavramını karşılamaktaydı. Arastalar, sonraları aralarına değişik esnafin da karışmasına rağmen, genellikle aynı malın ticaretini yapan dükkânlardan oluştukları için "terlikçiler arastası", "kürkçüler arastası", "baharatçılar arastası" gibi isimlerle de anılmışlardır. Bu çarşılar, başta camiler olmak üzere vakıf eserlere gelir sağlamak amacıyla onların yakınında veya bazı hallerde ayrı olarak uzağında yapılmışlardır. Özellikle camilere yakın yapılmalarının başlıca sebebi, o camiye cemaat temin etmek ve çevresine canlılık kazandırmaktır (Çam, 1991, s. 335).

Osmanlı kentinin ticaret ve zanaat işlemleri konutları dışarda bırakacak şekilde, dükkân ve atölyelerin sıralandığı bir veya daha fazla sokaktan oluşan tek bir alanda yoğunlaşır. Çarşı, kentleşmiş yüzölçümünün yüzde 6's1 ile yüzde 10'unu kaplar, mahallenin bütünü çarş1 diye adlandırılırdı. Pazar denilen yerler ise açık havada yer alan haftalık çarşı veya panayır biçimindedir. Bununla birlikte XVI. yüzyıla kadar çarşı ve pazarın eş anlamlı olarak kullanıldığ1 görülmektedir (Cerasi, 1999, s. 119). Osmanlı mahallesi şehir hayatını yansıtan fiziksel bir merkez olmasının yanı sıra bütün yerleşiklerin iştirak ettiği bir tarikatın, bir loncanın ya da bir milletin yerel birimi olarak görülebilir. Esnafın, mahallenin fiziki yapısına göre cami yakınından başlayarak kitapçılar, ciltçiler, deri eşya satıcıları ve terlikçiler şeklinde sıralandığı anlaşılır. Sonrasında bir imalat türü olan dokumacılar, daha sonra da marangozlar, çilingirler ve bakırcılar bulunurdu. Merkezden en uzakta ise demircilerin yer aldığ görülür. Şehir kapılarına yakın mekânlarda saraçlar ve eyerciler yer alır, bunlar daha çok köylülere hitap ederdi. En dişta debbağhane ve boyahaneler bulunur, çevrede de çömlekçiler hizmet ederdi (Ergenç, 1980, s. 104). Bu yerleşimin nedeni, yapılan bazı işlerin kokuya ve gürültüye sebep olmasından dolayı kalabalıktan uzak tutulmak istenmesi olmalıdır.

Çarşının kalbi ise bedestendir. Çevresine yerleşen dükkânların belirli bir sırası vardır. Sattıkları malların değeri ne kadar yüksekse dükkânların yeri de bedestene o kadar yakın olur. Bu çekirdeğin çevresindeki ilk çember hanlardan oluşur, bir sonrakinde değeri daha az olan dükkânlar, zanaat bölgeleri bulunur ve son olarak en diş bölgede deri atölyeleri ve pazarlar yer alırdı (Cerasi, 1999, s. 120). Genel hatlarıyla bir Osmanlı kentinin ticaret merkezi, bedesten ve etrafında gelişen han, arasta gibi yapıların oluşturduğu mekânlar bütünüdür. $\mathrm{Bu}$ bütünlük oluşurken, en küçük birim olan dükkânların bedesten ve hanların cephelerini sarmaları, üstü kapalı veya açık bir sokak etrafında birleşerek arasta ve çarşıları meydana getirmelerinin rolü büyüktür (Akar, 2009, s. 269). Osmanlı şehrinin asıl merkezini bedestenin oluşturduğu rahatça söylenebilir. Etrafında sadece geceleri konaklama hizmeti vermeyip aynı zamanda bir ticaret mekânı da olan hanlar bulunur. Ticari açıdan yayılma, şehirdeki 
bedestenden başlayan ve uzun çarşı denilen geniş caddenin odağında olduğu bir şekilde ilerler. Uzun çarşıya açılan sokaklarda çeşitli iş kollarına ait esnaf örgütleri yer alırdı (Ergenç, 1980, s. 106). Bu açıdan bakıldığında şehir yerleşmeleri içerisinde esnaf dükkanlarının, çarşıların ve bedestenin önemli bir payı olduğu anlaşılmaktadır.

\section{Yüzyıl Konya Esnafıyla İlgili Bazı Tespitler}

Selçuklu ve Osmanlı Devleti dönemlerinde büyük ve önemli bir şehir olan Konya'da ticari hayatın yoğunlaştığı, esnaf gruplarının dükkânlarının ve çarşılarının yer aldığı mekanlarla ilgili çeşitli bilgiler bulunmaktadır. Türkiye Selçukluları'nın başkenti olan Konya'da ticaretin geniş bir alana yayıldığı görülmektedir. Selçuklulardan önce açık bir kent durumunda olan Konya, Selçuklular döneminde çevresi surlarla çevrilerek kapalı kent haline gelmiş, eğitim, sağlık ve ekonomiyle ilgili kurumlar bu surların içinde örgütlenmiştir. İmalat, pazarlama ve hizmet üretme şeklinde gerçekleşen ekonomik örgütlenme çoğunlukla benzer işi yapan esnaf gruplarının çarşı, pazar ve hanlarda gün doğumundan gün batımına dek süren ticari ve iktisadi faaliyetlerden meydana gelmektedir. Söz konusu bu ekonomik yoğunluk, surun içindeki çarş1 ve pazarlarda gelişmiştir. XIII. yüzyıl başlarında Alaaddin Camii'nin doğusunda eski ve yeni çarşı diye isimlendirilen iki çarşı bulunmaktaydı (Uysal, 2010, s. 151).

Selçuklular döneminde sur kapılarından her biri bir ticaret yeri durumundaydı. Konya'nın yoğun ticaret bölgesini güneydoğu kesiminin teşkil ettiği söylenebilir. Daha net bir sınırlama yapmak gerekirse Atbazarı Kapısı ve Mevlana Dergâhı'ndan Bedesten'e kadar uzanan kısmın esnaf çarşıları ve pazar yerleriyle işgal edildiğini, tüccarların konakladıkları ve mallarını depoladıkları hanların da bu kesimde yer aldığını söyleyebiliriz. Şehrin iaşesi için yapılan ticaretin, şehrin kuzeydoğusunda yoğunlaştığını, çünkü Karamanoğulları'ndan beri kullanılan kapanın burada yer aldığını görebiliriz. Şehrin diğer kısımlarında bakkal ve ekmekçi gibi dükkânların dişında pek büyük sanat ve ticaret faaliyeti bulunmamakta idi (Ergenç, 1995, s. 38). Konya şehri Osmanlı hakimiyetine girdikten sonra da ticari açıdan hareketli ve canlı bir şehir görüntüsünü devam ettirmiştir. Evliya Çelebi, Konya'da yirmi altı adet han olduğunu ve bunlardan özellikle Atbazarı Kapısı dışındaki, Kösem Sultan'ın yaptırdığı hanın meşhur olduğunu aktarır. Ayrıca 1900 sultan çarşısı dükkânının varlığından bahseder. Yüzlerce dükkânın kargir ve bakımlı olduğunu belirterek bedestenden ise övgüyle söz eder. Bedesteni, "kâgir bina ve demir kapılı kanatlar ile örtülü kurşun kaplı" olarak niteleyerek, buradaki zengin tüccarlarda dünyanın en kıymetli eşyalarının bulunduğunu anlatır. Bununla birlikte Sipahpazarı, Saraçhane ve Tahtakale'nin de güzelliği ve düzenli oluşu Evliya Çelebi'nin aktardığı bilgiler arasında yer almaktadır (Çevik, 1986, s. 11).

Bugünkü şehir yapısı açısından bakıldığında, tarihi Konya Çarşısı, Mevlana Türbesi'nin de yer aldığı Mevlana Külliyesi'nin yakınında ve batı tarafında yer almaktadır. Belirtilen alan içerisinde, birçok cami ve dini yapı göze çarpmaktadır. Bunlar, Selimiye, İnce Minare, Kadı Mürsel, Şeker, İplikçi, Selimiye, Aziziye, Şerafettin, Kapı, Alâeddin, Sahib Ata camileri, Şems-i Tebrizi Camii ve Türbesi, Fürüş ve Sırçalı mescitleri gibi yapılar olup, bunların bir kısmı Selçuklular döneminden kalmadır. Ayrıca bu alana yakın durumda bulunan, Karatay, İnce Minare ve Sırçalı Medreseleri de bulunmaktadır (Şahinalp \& Günal, 2012, s. 162). Günümüzde bu bölge oldukça canlı bir ticaret alanı olarak varlığını korumaktadır. Bedesten adı verilen bölüm Konya halkının uğrak yeri durumundadır.

XVIII. yüzyılda Konya'da, aynı meslekle uğraşan esnaflar genellikle sûk denilen çarşıların bulunduğu sokaklarda toplu halde iş görürlerdi. Bunlar Alaaddin Tepesi'nin doğu ve güneyindeki alanda, dış kalenin Atbazarı Kapısı dışındaki yerlerde toplanmıştı (Küçükdağ, 
1989, s. 24). Osmanlı Devleti zamanında merkezi otoritenin güçlenmesiyle birlikte surlar eski önemini yitirmişlerse de şehre gelen yolların giriş noktalarını yine bu kapılar teşkil ediyordu. Her kapının çevresi birer sanat ve ticaret merkezi haline gelmiş, açılan dükkânlarla buralarda çarş1lar oluşmuştu (Ergenç, 1995, s. 33). Konya çarşısının merkezi, Alaaddin Tepesi'ni çevreleyen iç kaleden itibaren doğu yönüne doğru ve şehir içindeki önemli yolların etrafında şehir kapılarına doğru gelişmiştir. Aynı zamanda bu gelişme istikameti, o devirlerde de önemli miktarda ziyaretçi çeken Mevlana Külliyesi'ne doğru yönelmiştir (Şahinalp \& Günal, 2012, s. 164).

Şehre giriş noktalarında yani kapılarda ticari faaliyetlerin yoğunlaşması Osmanlı Devleti öncesi devirlerin karakteristik özelliğidir. Bunun iki nedeni olmalıdır. Birincisi, şehre gelenlerin kolayca uğrayabilecekleri yerler oluşu, ikincisi buraların özel bekçilerle korunan, güvenilir alanlar olarak görülmesidir. Bu özellik Osmanlı Devleti zamanında da devam etmiştir (Ergenç, 1995, s. 33). Konya'nın ticaret merkezi durumunda olan ve odağında Bedesten ve Uzun Çarşı bulunan alan, Konya'nın şehir olarak gelişimi ve bu gelişimin yönü üzerinde önemli bir rol oynamıştır (Şahinalp \& Günal, 2012, s. 163).

XVIII. yüzyıla ait belgeler incelendiğinde Konya esnaf geleneğinde bir süreklilik olduğu, esnafin Osmanlı Devleti'nin klasik döneminde konulan ve bir anlamda Anadolu Selçukluları ve Karamanoğulları'ndan intikal etmiş olan kurallarla mesleğini sürdürdüğü görülmektedir. Esnafin amirleri ve yerel yöneticiler geleneğe sadık kalmaya özen göstermişlerdir. Bununla birlikte zaman zaman geleneğin dışına çıkılarak istenmeyen durumların yaşandığı ve bunların tedbir alınarak kadim işleyişe döndürülmeye çalışıldığı da tespit edilmiştir. Konuyla ilgili 1701 tarihli bir belge bu duruma örnek olarak gösterilebilir. Söz konusu belgede, demirciler hırfetinden bazı kimseler, nalbandlar hırfetinden bazıları hakkında şikâyetçi olarak, kendilerinin eskiden beri öküz ve camus cinsini nalladıkları, bahsedilen çatal tırnaklılardan başkasını ise nalbandların nalladıklarını belirtmişlerdir. Hatta bu husus için kendilerine hüccet-i şer'iye ve ferman-1 şerif verildiğini belirten demirciler, Karaman Beylerbeyi'nin nal talebi karşısında nalbandlarla anlaştıklarını ve çatal tırnaklıları da nalbandların nallamaya başladıklarını ifade etmişlerdir. Nalbandlar da ifadelerinde bu durumu kabul etmiş, ücreti karşılığı demircilere başvurduklarını belirtmişler, mahkeme demircileri haklı bulmuştur (KŞS 39, 110-1). Görüldüğü üzere herkesin hangi işle uğraşacağı ince ayrıntılarına kadar belirlenmiştir. Esnafın düzeninin korunması için bazen hüccet, gerekirse de ferman çıkarıldığı dikkati çekmektedir.

Konuyla ilgili bir başka örnekte ise, mıhçılar esnafı, helvacı esnafindan biri ve yaymacı esnafindan biri hakkında şikâyetçi olarak, kendilerinin uğraşı olan hurda demir alım satımına helvacı ve yaymacıların karıştıklarını bildirmişlerdir. Neticede mıhçılar haklı bulunmuştur (KȘS 50, 252-3). Görüleceği üzere her esnafın sahası bellidir ve buna göre hareket etmek durumundadır. Bu düzene uygun hareket etmeyenler mahkeme tarafından men edilmekteydi. Bir başka örnekte de kendirci esnafı attar esnafı hakkında şikâyetçi olmuş, bir esnafın diğerine karışmadığını ve her sınıfın kendine mahsus metaı alıp satması konusunda emr-i ali bulunduğunu bildirmişlerdir. Buna rağmen attarların kendilerine mahsus olan kendir, ip ve yular alıp sattıklarını iddia etmişlerdir. Attarlar durumu kabul etmiş, neticede bundan sonra bu durumdan men edilmişlerdir (KŞS 53, 105-3). Anlaşıldığı üzere mahkeme, esnafın düzeninin bozulmasına kesinlikle müsaade etmemektedir.

Birbiriyle ilişkili iki esnaf grubunun anlaşmazlığı hakkında bir başka belge örneğinde saraçlar ile kösele tüccarı konu edilmiştir. Saraç esnafı, kösele tüccarı el-Hac Mehmed'den şikâyetçi 
olmuşlar, beyanlarında, bizler köseleyi Mehmed'den alır, vali ve mütesellime gerekli olduğunda eşyaları dikeriz ve tüccar ücretini onlardan alır demişlerdir. Ancak Mehmed'in vali tarafından kösele talep olursa benden siz alarak bedelini siz ödeyin şeklinde bir hal takındığını belirtmişlerdir. Yani valiye bizzat kendisi kösele vermekten imtina etmiştir. Hacı Mehmed ise bu konuda elinde hüccet bulunduğunu söyleyerek savunma yapmıştır. Ancak hücceti ortaya koyamamıştır. Neticede şehrin ileri gelenlerine sorulmuş ve onlar da sarracları haklı göstermişlerdir. Bu durumda el-Hac Mehmed bu tutumundan men edilmiştir (KŞS 53, 114-2). Görüleceği üzere mahkeme çelişkili bir durumda şehrin ileri gelenlerine danışma gereği duyuyordu. Leblebici esnafiyla arpacı esnafi arasında mahkemeye yansıyan olaylarla ilgili belgede de nohut satışıyla ilgili bir anlaşmazlık söz konusu edilmiştir. Leblebiciler nohutun kendi alanlarına giren bir meta olduğunu bildirerek arpacıların da nohut alıp satmalarıyla zarara uğradıklarını ifade etmişlerdir. Nohutun kıymetli bir madde olduğunu, arpacıların bu işi yaparken kendilerinin ödediği vergiyi de ödemediklerini belirtmişlerdir. Arpacılar bu durumu kabul etmiş, bundan sonra nohut alıp satmayacaklarına dair taahhütte bulunmuşlardır (KŞS $55,229-3)$.

Bu dönemde vakıf malı olan dükkânlarda kiracı olarak iş yapan esnaf da oldukça fazlaydı. Bunlar dükkânları aylık ya da yıllık olarak kiralayıp, bedelini vakfa öderlerdi. 1704 tarihli Şeyh Ahmed Efendi Vakfi muhasebesinde Habbaz Hasan, Neccar Emrullah ve Süleyman, Berber Ahmed, Gazzaz Mehmed, Mutaf Mustafa, Nalband Receb, Eskici Mehmed, postalc1 zimmi gibi esnaftan alınan kira bedelleri kayıtlıdır (KŞS 41, 115-1). Bununla birlikte bazı mahalle vakıflarına ait dükkânlar da mevcuttur. Mesela Pürçüklü Mahallesi vakfının dükkânları vardı (KȘS 41, 209-2, KŞS 52, 89-2). Yine 1763 yılında İbrahim Efendi Vakfi'na ait muytab, duhancı, kürkçü, berber, hallaç, ekmekçi, nalband, helvacı, kahveci, kasap dükkânları bulunmaktaydı (KŞS 100, 80-1). Vakıf kültürünün bir yansıması olan bu durum esnafin da bu kültürel yapı içinde etkin olduğunu göstermektedir.

Ticaret yapanların kurallara uyma durumu titizlikle takip ediliyordu. Vergilerin ödenip ödenmediğine dikkat edilirdi. Konuyla ilgili bir belgede başka yerlerden duhan (tütün) getirerek hile ile amediye vermeyen tüccarların men edilmesi hususunda yazılan bir tezkire söz konusudur. Duhan mukataasına mutasarrıf olan Hacı Abdülkadir bu durumla ilgili rahatsızlığını belirtmektedir (BOA, İE. ML., 119/11265). Yine Konyalı tütün tüccarı Hacı Ahmed'in altmış deve yükü tütünü başka bir yere götürdügü ifade edilen bir belgede, resmini ödemediği için Konya Valisi'ne emir yazılması rica edilmiştir (BOA, C. ML., 596/24596). Görüleceği üzere şehre giren ve çıkan malların vergileri dikkatle takip edilmiştir.

Osmanlı Devleti toplum yapısı içinde Konya esnafı, klasik Osmanlı esnaf teşkilatının kuralları çerçevesinde örgütlenmişti. Yukarıdan aşağıya düzenli bir yapı içinde işleyen bu sistemde üretim tüketim ve denetleme ilişkileri birbirinden bağımsız olarak yürütülmekteydi. Üretim sektöründe usta kalfa ve çırak çizgisinde işlenen hammadde, mamul madde haline geldikten sonra tüccarlar aracılığı ile dükkânlara ulaştırılarak satışa sunulur bu noktada hizmet sektörü devreye girerek tüketici ile üretici arasında köprü vazifesi görürdü. Ehl-i hıref ya da dükkân sahibi tüccarların hepsinin bir temsilcisi denetim ve yönetim sürecine doğrudan dâhil olurdu. XVIII. yüzyılın başlarına ait olan ve Karaman Eyaleti Valisi'ne verilen mallarla ilgili bir belgede esnaf yöneticilerinden bazılarının adına rastlanmaktadır. Belge incelendiğinde hem esnaf gruplarının adları hem de şeyh, ahibaba, bazarbaşı, nakib, kethüda, yiğitbaşı, duacı, çavuş, ustabaşı gibi yöneticileri ile ilgili bilgi sahibi olmak mümkündür. Buna göre; bakkallar yiğitbaşısı Mehmet Çelebi İbn el-Hac Osman, helvacılar yiğitbaşısı Kara Mustafa İbn el-Hac Ali, nalbandlar yiğitbaşısı Ahmed bin İsmail, semerciler yiğitbaşısı el-Hac Mehmed bin 
Hasan, kasaplar yiğitbaşısı Seyyid Muslu Çelebi bin Mehmed, keçeciler yiğitbaşısı el-Hac Mehmed bin Mahmud, debbağlar yiğitbaşısı Şaban bin İbrahim, haffaflar yiğitbaşısı İbrahim Çelebi ibn Ahmed, sarraclar yiğitbaşısı Mustafa bin Ali, duvarcılar yiğitbaşısı Hasan, mutaflar yiğitbaşısı Mustafa bin Mehmed, ekmekçiler yiğitbaşısı Seyyid Mehmed bin Şaban isimli yiğitbaşılar merkezi otoriteye karşı kendi sınıfını temsil etmektedir. Bu belgede Konya'daki esnafin tamamı yer almamakta, valiye hizmet sunan esnaf sıralanmaktadır. En fazla ödemenin bakkallar cemaatine yapılması da dikkat çekicidir (KŞS 40, 25-1, 25-2).

Konya esnafının düzeniyle alakalı, 1710 tarihli bir sicil kaydı Konya'da yiğitbaşılık kurumunun işleyişi hakkında önemli bilgiler içermektedir. Belgeye göre kasap esnafindan bir grup mahkemeye başvurarak, esnaf arasında meydana gelen bazı hususlar için aralarından birini yiğitbaşı tayin etmenin eski bir adet olduğunu bildirmişlerdir. Orada hazır bulunan Ali oğlu Mehmet Beşe'nin de ehl-i vukuf ve yiğitbaşılığa layık olduğunu belirterek, adı geçenin eski usul üzere bir seneliğine yiğitbaşı tayin edilerek kendisine temessük verilmesini istemişlerdir. Mehmet Beşe de kasaplar esnafının yiğitbaşısı olmayı ve gerekli hizmeti vermeyi taahhüd etmiş ve ataması gerçekleşmiştir (KŞS 44, 128-2). Yiğitbaşının esnafin kendi arasından seçilerek kadı tarafından onaylandığı ve bu şekilde göreve başladığ anlaşılmaktadır.

Yiğitbaşılık kurumu ile ilgili bilgiler içeren 1714 tarihli bir belgede yukarıdaki belgede olduğu gibi, Karaman Beylerbeyi’ne verilen malların ücretinin alındığı aktarılırken bazı yiğitbaşıların da adı geçmektedir. Bunlar da şu şekilde sıralanmıştır: Mutaf yiğitbaşısı Abdurrahman bin Ahmed, şerbetçiler yiğitbaşısı Hasan bin Sefer, keçeciler yiğitbaşısı Abdülgaffar bin Ramazan, demirciler yiğitbaşısı es-Seyyid Ali bin Satılmış, semerciler yiğitbaşısı es-Seyyid Mustafa ibn es-Seyyid Ali, etmekçiler yiğitbaşısı Mehmed bin Ali, bakkallar yiğitbaşısı Süleyman bin Ahmed, haffaflar yiğitbaşısı Mustafa bin Mehmed, kasablar yiğitbaşısı Ahmed bin Abdüsselam, tüccarlar yiğitbaşısı Molla Mehmed bin Musa, nalbandlar yiğitbaşısı Ahmed bin İsmail. Bu esnaf gruplarının ücreti yiğitbaşıları tarafından alınmış, daha sonra ilgili kişilere dağıtımı sağlanmıştır (KŞS 45, 81-1). Anlaşılacağı üzere XVIII. yüzyılın ortalarında da yiğitbaşılık kurumu önemini muhafaza etmekteydi.

Yine validen alacakların tahsil edilmesiyle ilgili bir belgede çeşitli esnaf gruplarının adı geçmekte, söz konusu esnafın vekil-i şer'ileri olarak gösterilen isimler arasında bir kısmının yiğitbaşıları da zikredilmektedir. Kasap esnafının yiğitbaşısı Ali Bey İbn-i Süleyman, Attar esnafinın yiğitbaşısı İbrahim bin el-Hac Mehmed, libasçılar yiğitbaşısı Mustafa bin Abdi burada geçen isimlerdir (KŞS 57, 116-2). 1762 tarihli başka bir belgede, Türkmen kürkçü esnafi üzerine Mehmed adlı şahsın yiğitbaşı olarak tayin edildiği kayıtlıdır (KŞS 100, 118-1). 1753 yılında haffaflar yiğitbaşısı olarak görülen Ahmed'in bu tarihte göreve yeniden atandığ anlaşılmaktadır. Yaklaşık on yıl sonra da görevi oğlu Derviş Mehmed'e devretmiştir (Baykara, 1990, s. 207). 1763 tarihli sicil kaydında da yine haffaflar yiğitbaşısı Ahmed Halife'nin kendi rızasıyla oğlu Mehmed lehine vazifesinden feragat etmesi konu edilmiştir. Mehmed bu göreve uygun bulununca bu talep kabul edilmiş ve yeni bir berat çıkarılmıştır (KŞS 100, 129-2).

Yiğitbaşılık kurumunun XVIII. yüzyılın sonlarına kadar varlığını sürdürdüğü görülmektedir. 1787 tarihli bir belgede nalbant esnafının demircilerle ilgili yaşadığı bir sorunun mahkemeye taşındığ 1 ve burada nalbant esnafının yiğitbaşısı olarak Mehmed bin Ömer'in de yer aldığ1 görülür (KŞS 65, 19-2). 1793 tarihli bir kayıtta ise helvacıyan esnafının yiğitbaşısı olarak Mustafa Beşe bin İbrahim adı geçmektedir. Tekâlif talebiyle ilgili bu kayıttan yiğitbaşıların 
önemini koruduğu anlaşılmaktadır (KŞS 66, 17-2). Bu örneklerle yiğitbaşı tabir edilen görevlilerin XVIII. yüzyılda Konya'da etkin bir şekilde faaliyet yürüttüklerini söylemek mümkündür.

Belgelerde adı geçen bir başka yönetici ise bazarbaşıdır. XVIII. yüzyılın başlarında Konya'da İsmail Çelebi adlı kişinin bazarbaşı olarak görev yaptığı görülmektedir (KŞS 38, 119-1; KŞS 39, 9-1, 88-1). Bazarbaşı tüm esnafın bir temsilcisi durumundaydı. Devletle olan ilişkilerde bir aracı olarak nitelendirilebilir. İsmail Çelebi'nin de bu şekilde bir rol oynadığ anlaşılmaktadır. Bakkal, helvacı, kasap gibi çeşitli esnaf grupları onun önderliğini ikrar etmişlerdir (KŞS 38, 119-1). İsmail Çelebi'nin bu görevi bir süre devam ettirdiği ve 1703 yılına dek bu görevde bulunduğu anlaşılmaktadır (KŞS 41, 16-1) 1703 yılında ise Konya bazarbaşılığına Hacı Ali Ağa'nın atandığı Kadı Mehmed Efendi'nin merkeze gönderdiği ilamdan anlaşılmaktadır (BOA, AE. SMST II, 1/52). 1715 yılında Halep valisi Ali Paşa'ya verilen erzakın listelendiği kayıtta ise bazarbaşı olarak Ahmed Çelebi'nin adı geçmektedir. Yine aynı kayıtta önceki bazarbaşı olarak da Molla Ebubekir ismi verilmektedir. Burada erzakların bir kısmının bazarbaşı tarafından temin edilerek valiye sunulduğu ve parasının da yine bazarbaşı tarafından tahsil edildiği görülmektedir (KŞS 45, 3-1). Bir başka belgede ise Karaman Valisi'ni teftişe gelen müfettişe sunulan masraf listesinde semerciler yiğitbaşısı eliyle sarayın yastıklarına kılıflık top verildiği görülmekte, Bazarbaşı Ahmed Çelebi'den de bahsedilmektedir. Burada ilginç bir nokta da masraf listesinde bazarbaşıllk için çıkarılan hüccete verilen harcın da listeye eklenmiş olmasıdır. Bazarbaşılığın hüccetle tevcih edildiğini ve bunun da bir masrafı olduğu anlaşılmaktadır (KŞS 45, 10-1).

Bazarbaşılık için berat çıkarıldığ 1 da görülmektedir. Bununla ilgili bir berat örneği, şu ifadelerle son bulmaktadır: “...virilen rü’us-1 hümayunum mucibince müceddeden bu berat-1 hümayunu virdim ve buyurdum ki mezkur Ebubekir varup Konya'da bazarbaşı olup bundan evvel bazarbaşı olanlar ne minval üzere mutasarrıf olagelmişler ise mezbur dahi ol minval üzere mutasarrif ola ol babda ref olunan merkum Ahmed ve taraf-1 ahardan kimesne dahl ve taarruz kılmayalar..." (KŞS 45, 293-2) Bu belge bazarbaşıllkla ilgili birçok bilgi içermektedir. Öncelikle esnaf ve çarşı sakinlerinin kendi aralarında belirledikleri birini kadı huzurunda bazarbaşı olarak seçtikleri ve bunu kadı müraselesiyle resmi bir hale getirdikleri görülmektedir. Burada bu duruma aykırı bir şekilde bazarbaşılığı üzerine alan birinin usulsüzlükleri görülmüş ve mesele başkente taşınmıştır. Neticede usulsüzlük yapan kişiden bazarbaşılık alınarak güvenilir ve herkes tarafından kabul edilen başka birine bu görev tevcih edilmiştir. Belgede Bazarbaşı Ahmed Çelebi'nin vilayet için yapılan masraflarda usulsüzlüğünün tespit edildiği belirtilmektedir. Anlaşıllyor ki bazarbaşı denetime tabi tutulmakta ve yaptığı faaliyetlerin uygunluğu incelenmektedir. Buradan çıkan bir başka sonuç ise bazarbaşılık için kadı hücceti gerekirken, anlaşmazlık durumlarında berat alınması ihtiyacının hâsıl olduğudur.

1727 tarihli bir ferman suretinde, Konya esnafının teşkilat ve düzeni hakkında çok önemli bilgiler bulunmaktadır. Belgeye bakıldığında bezzâz, haffaf, zerger ve sabbağ esnafının aynı şeyh ve kethüda tarafindan yönetildikleri ve bunların ferman ile görevlendirildikleri anlaşılmaktadır. Konya esnaf teşkilatında şeyh ve kethüda isimlerine yönetici olarak rastlanması geleneksel yapının korunduğu anlamına gelmektedir. Aynı belgede esnafin yetişme tarzıyla ilgili de önemli bilgiler bulunmaktadır. Bir ustanın yanında çıraklık yapmadan, sanatı tam olarak öğrenmeden ve kurallara uygun olarak başka çıkmadan (ustalık vasfinı kazanmadan) sanatı işleyip dükkân açmanın mümkün olmadığı anlaşılmaktadır. Osmanlı Devleti'nde esnaf teşkilat düzeninde usta-çırak ilişkisine verilen önem Konya'da da 
aynen korunmuştur. Bu durum o kadar önemli görülmektedir ki padişaha kadar intikal eden şikâyetlere konu olmaktadır. Merkezi hükümet de bu duruma kayıtsız kalmayıp konuyla ilgili fermana hükmetmiştir (KŞS 50, 259-3).

Konya esnafında bir yönetici olan esnaf şeyhleri belgelerde de görüleceği üzere eskiden beri esnafin her türlü işini yapmakla görevliydiler. Bunlar esnafın kendi aralarında uygun gördükleri birini kadıya bildirerek onay almalarıyla atanmaktaydı. Bazen merkezden berat istendiği de görülmektedir. Esnaf, şeyhin görevlendirilmesinde olduğu kadar görevden alınmasında da etkili olurdu (Tuş, 2007, s. 203). Belgelerde çok fazla karşılaşılmayan yöneticilerden biri olan şeyh ile ilgili bir kayıt dikkat çekicidir. Bu belge de görevlendirmeyle ilgili bir berat sureti olup,

\section{"Berat-ı meşihat-ı bakkalan bi- ism-i Seyyid Süleyman}

\section{Nişan-ı şerif-i alişan hükmü oldur ki.}

Medine-i Konya'da vaki bakkallar ve kürkçüler ve berberler esnafinın şeyhi olan işbu rafi-i tevki-i refiü'ş-şan-ı hakani es-Seyyid Süleyman bil- fiil berat-l şerifimle mutasarrıf olup hizmetinde kusuru ve mucib-i azli yoğiken ahardan hilaf-ı inha ile üzerinden Mehmed alup külli gadr itmekle ref olunup gerü mezbura ibka ve mukarrer kllınmak babında yedinde olan berat-l atiki mucibince inayet taleb itmeğin vaki ise sadaka idüp bu berat-ı hümayunumu virdim ve buyurdum ki..." şeklinde kayıtlar içermektedir (KŞS 45,294-2). Burada önce bakkalların şeyhi olarak zikredilen Seyyid Süleyman ismi daha sonra kürkçü ve berberlerin de şeyhi olarak gösterilmiştir. Anlaşıldığ 1 üzere şeyhlik için berat gerekmektedir ve usulsüz şekilde görev alan kişi hemen el çektirilmiştir. Seyyid Süleyman'ın beratı yenilenerek göreve iadesi sağlanmıştır.

1753 yılında Konya'da, şeyh-i seb'a unvanıyla görev yapan bir yönetici bulunduğu anlaşılmaktadır. Bu tarihte şeyh-i seb'a olan Abdülkerim'in vefat ettiği ve sonrasında oğulları Abdullah ve Halil'e bu görevin tevcih edildiği görülmektedir. Sonrasında Abdullah vefat etmiş ve görev Halil'de kalmıştır (Baykara, 1990, s. 205). 1762 tarihli bir sicil kaydında, birçok esnaf grubu sayılarak bunların şeyhlerinin Hafız Mahmud olduğu belirtilmiştir. Bu gruplar, bakkallar, berberler, saraçlar, kalaycılar, kürkçüler, çömlekçiler, bezirciler, muytablar, bazarcılar ve gazzazlar ile sair esnaf olarak kaydedilmiştir. Hafız Mahmud'un berat-1 ali ile bu görevde olduğu da belirtilmiştir. Şeyhin görevine dişardan müdahaleler olduğu için şikâyetçi olduğu anlaşılmaktadır (KŞS 100, 127-1). Görüleceği üzere, bu tarihte de birçok esnaf grubunun ortak bir şeyhi bulunuyordu.

1763 tarihinden itibaren haffaf ve dikici esnafı şeyhliğini sırayla Abdullah ve Halil, Ahmed, yeniden Abdullah ve Halil, yeniden Ahmed, oğlu Mehmed, Halil ve el-Hac Mustafa'nın yürüttügü görülmektedir (Baykara, 1990, s. 208). 1765 tarihli bir belgede haffaf ve dikici esnafindan bazılarının mahkemeye başvurduğu ifade edilerek Şeyh Abdullah Efendi'den bahsedilmektedir. Şeyh Abdullah'ın berat-1 ali ile bu görevde olduğu belirtilerek esnafin işlerine baktığı belirtilmektedir (KŞS 58, 88-2). Belgeden adı geçen şeyhin tüm esnafin şeyhi olup olmadığ 1 anlaşılamamaktadır. Ancak haffaf ve dikicilerin şeyhi olduğu ve onların her türlü işlerine baktığı açıktır. Yine aynı tarihli başka bir kayıtta da Şeyh Abdullah Efendi'nin adı geçmekte ve haffaf ve dikicilerin müştereken şeyhi olduğu belirtilmektedir. Kaşıkçı Ahmed adlı birinin şeyhin işlerine müdahalesi söz konusu olmuş, adı geçen kişi bundan men edilmiştir (KŞS 58, 162-3). Ayrıca bu tarihte nalband şeyhliğinin es-Seyyid Mehmed ve es- 
Seyyid İbrahim'den es-Seyyid Mustafa'ya geçtiği de görülmektedir. Bu tarihten sonra sırasıyla es-Seyyid Mehmed ve es-Seyyid İbrahim yeniden, Şeyh İbrahim, Hafiz Mehmed ve es-Seyyid Hüseyin nalbandlar şeyhliği görevini yürütmüşlerdir. Yine 1783 yılında külahçılar esnafı şeyhi Hüseyin'in vefatı üzerine oğlu Derviş Hasan'ın göreve getirildiği dikkati çekmektedir (Baykara, 1990, s. 206-207). Anlaşılacağı üzere yüzyılın ikinci yarısında da Konya' da şeyhlik kurumu varlığını ve esnaf üzerindeki etkisini devam ettirmekteydi.

Belgelerde çok fazla karşıllaşılmayan yöneticilerden biri de ahi babadır. Bununla birlikte XVIII. yüzyılda Konya'da ahi babalık kurumunun yaşadığını ve özellikle debbağlar arasında önemli bir yerinin bulunduğunu görmekteyiz. XVIII. yüzyılın başlarında sicillerde ahi baba adına rastlanmış olup ismi el-Hac Osman şeklinde kayıtlıdır (KŞS 39, 13-1, 24-1, 73-1, 1411) Merkezden gönderilen bir buyruldudan, Konya'da daha önce ahi baba olarak görev yapan Mehmed'in vefat ettiği ve 1711 yılında Debbağ Süleyman'ın bu göreve getirildiği anlaşılmaktadır (BOA, C.BLD, 40/1956). Anlaşılacağı üzere ahi baba merkezden de görevlendirilebiliyordu. 1718 yılında ise ahi baba olarak el-Hac Süleyman adı geçmektedir (KŞS 48, 200-1). 1730-1731 yıllarında el-Hac Mehmed ibn el-Hac Abdurrahman'ın ahi baba olarak görev yaptığı anlaşılmaktadır (KŞS 52, 27-3, 43-5). Ahi babanın debbağ esnafı arasındaki anlaşmazlıkların çözümünde rol oynadığı görülmektedir (KŞS 52, 244-1). 1736 yılında da adı tespit edilemese de bir ahi babanın varlığı bilinmektedir (KŞS 53, 10-1). Sonraki yıllara ait bir belgeden anliyoruz ki bu kişi de hala görevine devam eden el-Hac Mehmed'tir. Sözü geçen el-Hac Mehmed 1740 yılına kadar görevini sürdürmüştür (KŞS 54, 22-4, 60-1, 119-2). 1742 yılında ise ahi baba olarak Hacı İbrahim bin Ahmed adı geçmektedir (KŞS 55, 229-1).

Esnaf arasında çıkan sorunlar kanun-i kadimdeki usule göre ve esnaf ileri gelenleri ile yapılan istişarelerle çözülmektedir. Yukarıda anılan kethüda, şeyh ve yiğitbaşıların bu istişarede ortak bir noktaya gelerek sorunun çözümüne katkıda bulundukları görülmektedir. Bazen de doğrudan esnafa danışılarak sorunların çözüm yoluna gidildiği anlaşılmaktadır. XVIII. yüzyılın ikinci yarısına ait, 1772 tarihli bir sicil kaydında, kösele gibi bazı hammaddeler konusunda saraç esnafının yaşadığı bir sorun konu edilmiştir. Kendilerinin o zamana kadar amel-i kadim üzere kösele aldıklarını ancak Seyyid Veli adlı kişinin buna aykırı hareket ederek kösele alıp sattığını bildirmişlerdir. Bu anlaşmazlığın çözümü konusunda şehirdeki esnafa danışıldığı ve şehirde bulunan otuz iki nev' esnafın ihtiyar, meşayih ve ahi babalarına sorulduğu anlaşılmaktadır. Neticede sorunun esnaf arasındaki mevcut yani kadimden gelen adetler üzerine çözülmesi gerektiği tasdik edilmiştir (KŞS 61, 34-2). Anlaş1liyor ki geleneksel düzen korunmak istenmekte ve bu düzenin devamını sağlamak için çaba sarf edilmektedir.

Esnaf teşkilatı içerisinde yeri olan bir başka yönetici de muhtesibtir. Konya'da XVIII. yüzyılda muhtesiblik kurumu varlığını sürdürmekteydi. Yüzyılın başlarında muhtesib olarak es-Seyyid Süleyman Çelebi bin es-Seyyid İbrahim adı geçmektedir (KŞS 39, 76-1, 94-2). 1703 yılında ise Konya ihtisab mukataasının Mevlevi Mehmed Efendi'nin uhdesinde olduğu görülmektedir (BOA, AE. SMST. II, 69/7297) 1708 yılında, el-Hac Mahmud, malikane ihtisab mukataasının uhdesinde olduğu kişi olarak karşımıza çıkmaktadır (BOA, AE. SAMD. III, 104/10289). 1723 yılında Ahmed Beşe ibn-i Mustafa muhtesiblik görevini yürütürken, (KŞS 49, 2-3) 1731 tarihinde el-Hac Ahmed Ağa muhtesib olarak kayıtlarda yer almaktadır. Buradaki ağa unvanı ihtisab ağalığından dolayı verilmiş olabilir (KŞS 52, 120-4). 1736 yılında ise Mehmed Ağa ibn Mahmud muhtesib olarak belirtilmektedir. Burada da ağa unvanı verildiği dikkati çekmektedir (KŞS 53, 174-4). Mehmed Ağa'nın vefatı sonrası ise Konya İhtisab Mukataası Derviş Ahmed'e tevcih edilmiştir (BOA AE. SMHD. I, 193/15042). Derviş 
Ahmed Ağa'nın bu görevi 1753 yılına kadar sürdürdüğü görülmektedir. (BOA, AE. SMHD. I, 257/20922). 1759 yılında ise ihtisab emini olarak Hidayetullahzade Ahmed Ağa'nın adına rastlamaktayız. (BOA, AE. SMST. III, 48/3473) 1769 tarihinde Seyyid Zeynelabidin Konya ihtisabının tasarruf sahibi olarak karşımıza çıkar. (BOA, AE. SMST, III, 24/1625) Yüzyılın sonlarında ise Konya İhtisab Mukataası Çelik Paşazade Hüseyin'in uhdesinde bulunmuştur. (BOA, C.ML. , 570/23334, 431/17486)

Muhtesib ya da ihtisab ağası, görevini yürütürken uhdesinde bulunan vergilerin toplanmas1 hususunda bazı yardımcılar görevlendirirdi. Bunlara koloğlanı, başlarına ise kolbaşı denilirdi (Tuş, 2007, s. 211) 1716 tarihli bir belgede, ekmekçi esnafından bazılarının mahkemeye başvurarak koloğlanı es-Seyyid Mustafa hakkında şikâyetçi oldukları görülmektedir. Şikâyetin sebebi koloğlanının kendilerinden narh akçesi adı altında ve muhtesib ağası adına haksız taleplerde bulunduğu iddiasıdır. Koloğlanı bunlardan bazılarını kabul edip bazılarını inkar edince kabul ettiklerini geri vermiş ve bundan sonra koloğlanı olmaması için tenbih edilmiştir (KŞS 47, 69-3). Anlaşılacağı üzere muhtesibin görevlendirdiği kişiler bazen görevini suiistimal etmişlerdir. Ayrıca muhtesibin narh akçesi adı verilen bir vergi türünü de esnaftan talep ettiği görülmektedir.

\section{SONUÇ}

Osmanlı Devleti'nde esnaf teşkilatı çok önemli bir organizasyondur. Bu organizasyon kendi içinde hiyerarşik bir yapıya sahip olmakla birlikte merkezi hükümetle ve yerel idarecilerle de uyum içinde faaliyetlerini sürdürmüştür. Esnafın teşkilatı tarihsel kökenleri olan ve bu kökenlerden beslenen bir yapıya sahipti. Fütüvvet ve ahilik geleneklerinin izleri son dönemlere kadar kendini hissettirmiştir. Esnaf teşkilatında birçok yönetici bulunmakta olup bunların her birinin görev ve yetki alanları belirgin bir şekilde ayrılmıştır. Yerel anlamda teşkilatın en üst yöneticisi aynı zamanda yerel idarenin de başı olan kadıdır. Muhtesib, şeyh, kethüda, yiğitbaşı gibi yöneticiler de, esnafla ilgili çeşitli konularda yetki sahibi olmuşlardır.

Orducu uygulaması esnaf teşkilatının merkez ile sıkı ilişkiler geliştirdiğinin ve merkezi idareye destek verdiğinin bir göstergesidir. Osmanlı Devleti'nin büyük devlet olmasının en önemli sebeplerinden biri teşkilatlı şekilde hareket etmesidir. Mesela seferlerde askerin günlük hayatını normal bir şekilde devam ettirebilmesi için de düzenli bir sistem kurulmuştur. Bununla birlikte diğer sosyal kesimler gibi esnafın da sefer giderlerine katkı sağlaması beklenmiş ve bu katkının düzenli ve sistemli bir şekilde yerine getirilmesi için gayret sarf edilmiştir. Ancak doğal olarak bazı sorunlarla da karşılaşıldığı görülmektedir. Özellikle darlık ve kıtlık zamanlarında her kesim gibi esnaf da zor durumlara düşmüş ve istenen katkıyı sağlamakta yetersiz kalmıştır. Ayrıca meydana gelen suistimaller de orducu sisteminin işleyişinde rahatsızlıklara yol açmıştır. Bunlara rağmen, özellikle devletin ihtişamlı dönemlerinde İstanbul, Edirne ve Bursa gibi büyük şehirlerden toplanarak sefere fiilen katılan esnaf gruplarının, seferin önemli bir aktörü olduğu rahatlıkla söylenebilir. Bununla birlikte imdâd-1 seferiyye adı verilen verginin tahsili konusunda da yine esnaf teşkilatı bütün üyeleriyle üzerine düşen görevi yerine getirmiştir.

Esnaf teşkilatının uygulayıcısı olduğu narh uygulaması ise yine Osmanlı Devleti'nin teşkilatçılık anlayışının en ilginç örneklerindendir. Geçmişi oldukça eski olan ve tarihi temellere dayanan bu uygulama Osmanlı Devleti'nde de en iyi şekilde uygulanmaya çalışılmıştır. $\mathrm{Bu}$ uygulamayla hem haksız kazancın önüne geçilmiş hem de tüketicinin korunması sağlanmıştır. 
Konya esnafı da bu genel yapı içerisinde ve hemen hemen aynı kurallarla varlığını sürdürmüştür. Bununla birlikte XVIII. yüzyıl Konyası'nda, esnafın kendi arasında ve bazen de idarecilerle birtakım sorunlar yaşandığı görülmektedir. Bu durum hem dönemin şartları hem de insan unsuru düşünüldüğünde doğal karşılanmalıdır. Aynı zamanda, bu devirde de Konya esnafi merkezi idareye katkılar sunmuştur. Orducu uygulamalarında daha çok nakdi anlamda rol oynayan Konya esnafı, imdâd-1 seferiyye konusunda da kendisine verilen sorumluluğu yerine getirmiştir. Özellikle sicillerdeki bazı örnekler bu durumu açıklar niteliktedir.

Konya şehrinde birçok çarş1, esnaf tarafından mekan olarak görülmüş ve halkın istifade etmesi için kullanılmıştır. Bu çarşıların bulundukları yerler, ticaret ve sosyal hayat açısından bazı ipuçları elde etmek açısından önemlidir. XVIII. yüzyılda bazı yerlerin ticaret ve üretim açısından Konya'nın kalbi durumunda olduğu, bazı yerlerin ise nispeten sönük kaldığı söylenebilir. Özellikle Atbazarı Kapısı civarı, Alaaddin Tepesi ile Mevlâna arasında kalan bölge son derece canlı ticaret mekanı özelliği taşımıştır. Arşiv belgelerinden elde edilen veriler incelendiğinde yine Konya şehrinde XVIII. yüzyılda çeşitli meslek dalları ve bu dallarda çalışan esnaf grupları ile karşılaşılmaktadır. Bunların bir kısmı çarşılarda bir kısmı da mahallelerdeki dükkânlarda hizmet vermişlerdir.

XVIII. yüzyıl Konya esnafı bir nevi Osmanlı Devleti esnaf teşkilatının bir yansımasıdır. Bu durum bazı istisnalar dışında belgelerle de ortaya çıkmaktadır. XVIII. yüzyıl gibi karışık bir dönemde Konya esnafının organizasyonunu koruduğu da rahatlıkla ifade edilebilir.

\section{KAYNAKÇA}

Akar, T. (2009). Osmanlı kentinde ticari mekanlar. Tarih Araştırmaları Literatür Dergisi, 7(13), 267-292.

Barkan, Ö. L. (1984). Osmanlı İmparatorluğu'nda esnaf cemiyetleri. İstanbul Üniversitesi İ.F.M.(1-4), 39-46.

Baykara, T. (1990). Osmanlı taşra teşkilatında XVIII. yüzyılda görev ve görevliler. Vakıflar Genel Müdürlüğü Yayınları.

Berkes, N. (1970). 100 soruda Türkiye iktisat tarihi (Cilt II). Gerçek Yayınevi.

Cerasi, M. (1999). Osmanlı kenti. Yapı Kredi Yayınları.

Çam, N. (1991). Türkiye diyanet vakfi İslam ansiklopedisi. Türkiye Diyanet Vakfı İSAM.

Çevik, M. (1986). Seyahatname (Cilt III-IV). Üçdal Neşriyat.

D'ohsson. (t. y.). 18. yüzyll Türkiyesinde örf ve adetler. Tercüman 1001 Temel Eser.

Ergenç, Ö. (1980). Osmanlı şehrinde esnaf örgütlerinin fiziki yapıya etkileri, Birinci uluslararası Türkiye'nin sosyal ve ekonomik tarihi kongresi tebliğleri, Meteksan Limited Şirketi.

Ergenç, Ö. (1995). XVI. yüzyllda Ankara ve Konya. Ankara Enstitüsü Vakfı Yayınları.

Ergin, O. N. (1995). Mecelle-i umur-ı belediyye (Cilt I-II). İstanbul B.B. Kültür İşleri Daire Başkanlığı Yayınları.

Genç, M. (2000). Osmanlı imparatorluğunda devlet ve ekonomi. Ötüken Neşriyat.

Kala, A. (1995). Türkiye diyanet vakfi İslam ansiklopedisi (Cilt 11). Türkiye Diyanet Vakfı İSAM.

Kazıcı, Z. (2003). Osmanli'da toplum yapısı. Bilge Yayınları.

Küçükdağ, Y. (1989). Lale Devri'nde Konya (Yayımlanmamış Doktora Tezi). Selçuk Üniversitesi Sosyal Bilimler Enstitüsü, Konya.

Mantran, R. (1990). 17. yüzyllın ikinci yarısinda İstanbul (Cilt I-II). TTK Basımevi.

Özkaya, Y. (2008). 18. yüzyılda Osmanlı toplumu. Yapı Kredi Yayınları. 
Şahinalp, M. S., \& Günal, V. (2012). Osmanlı şehircilik külttüründe çarşı sisteminin lokasyon ve çarşı içi kademelenme yönünden mekansal analizi. Milli Folklör Uluslararası Kültür Araştırmaları Dergisi, (93), 149-168.

Tabakoğlu, A. (2000). Türk iktisat tarihi. Dergah Yayınları.

Tuş, M. (2007). Sosyal ve kültürel açıdan Konya. Tablet Yayınları.

Uysal, M. (2010). Tarihsel süreçte geleneksel Konya çarşısı için bir mekansal analiz. Milli Folklör Uluslararası Kültür Araştırmaları Dergisi, (86), 149-162.

\section{Arsiv Belgeleri}

Başbakanlık Osmanlı Arşivi Ali Emiri Tasnifi.

Başbakanlık Osmanlı Arşivi Cevdet Tasnifi.

Başbakanlık Osmanlı Arşivi İbnülemin Tasnifi.

Başbakanlık Osmanlı Arşivi Divan-1 Hümayun Mühimme Defterleri Kataloğu.

Konya Şeriyye Sicilleri: $38,39,40,41,44,45,47,48,49,50,52,53,54,55,57,58,61,65,66,100$ numaralı defterler. 


\section{EXTENDED ABSTRACT}

\section{General Characteristics of Tradesmen in the Ottoman State and Some Determinations About the 18th Century Konya Tradesmen}

The Ottoman State ruled for a long time and was a great world state. It is known that this state has very important institutions and organizations both socially and economically. One of the most important of these is the organization of tradesmen. The organization of tradesmen, which is a product of a deep-rooted tradition, has played very important roles socially and economically. The idea of "futuvvet" and "ahilik" are the most important elements that form the basis of this organization. The structure, which was shaped in the previous TurkishIslamic states, continued its influence throughout the existence of the Ottoman State.

The organization of the tradesmen in the Ottoman State period had a highly organized and disciplined structure. This event can be clearly demonstrated by many documents. Although the concepts such as "ahilik", "lonca" and "gedik" are used from time to time, the structure is generally preserved. In the local sense, there was a governing committee headed by the "kad1" and they took decisions on many issues related to the tradesmen. Tradesman's upbringing, apprenticeship to squat and eventually mastery were also subject to a very strict supervision and training process. This audit process is seen in the price policy of the tradesmen as "narh" system.

There are many managers in the tradesmen organization, and each of them has a clear division of duty and authority. In the local sense, the top manager of the organization is the kad1, who is also the head of the local administration. Managers such as "muhtesib", "sheikh", "kethüda", "yiğitbaşı" also had authority on various issues related to tradesmen.

It is also seen that tradesmen contributed to Ottoman expeditions and undertook active duties under the name of "orducu" tradesmen. The "orducu" tradesmen, who fulfilled all the needs of the soldiers at the time of the expedition, at the scene of the war and in the time of the return and at an officially fixed price, would go on the expeditions with the professional tools and raw materials that they would use in production. However, some of the difficult and nontransportable needs, such as supplies and sheep, were obtained from the nearest settlements.

One of the ways that tradesmen make contributions to Ottoman State campaigns is cash payment. This concept corresponds to the civil tax received from the people in return for battle costs. It is clear that these monies collected to be spent on war expenses is an extraordinary way of financing when it is not possible to cover expenses with normal government revenues. It is understood that the tradesmen took responsibility for the collection of this tax together with other elements and efforts were made to fulfill this duty.

The bazaars, where the tradesmen were together, constituted an important center of social life. In order to both facilitate the work of the consumer and provide control, the tradesmen who did the same work or sold the same goods were in the same bazaar or inn as much as possible. Even though the bazaars where the tradesmen who practiced the same profession in Ottoman cities were called with local names, their functions were the same. "Suk" and "arasta" were among these names. The heart of the bazaar is the bedesten. The shops were placed around the bedesten in a certain order. 
Konya, an ancient Turkish-Islamic city, has become one of the most important centers of Ottoman culture since the fifteenth century when it entered Ottoman rule. In Konya, the tradesmen organization carried the traces of this culture and formed a picture in accordance with the general structure of the Ottoman State. In the eighteenth century it is understood that this situation is preserved with some exceptions. Especially the kadı registers contain a lot of documents about this issue. Konya tradesmen maintained the organizational structure in the eighteenth century, applied the system of narh, contributed to the army in the expedition times, and took an important place in social life with its bazaar and shops.

In the documents examined, some information about the tradesmen managers in Konya was obtained. It is seen that there is a continuity in the tradition of tradesmen in Konya, and that the tradesmen continued their profession with the rules set in the Ottoman classical period and in a sense inherited from the Anatolian Seljuks and Karamanoğulları. The managers of the tradesmen and local administrators took care to stick to the tradition. However, it has also been determined that undesirable situations are experienced from time to time by going beyond the tradition and these are tried to be returned to the ancient functioning by taking precautions.

"International Journal of New Approaches in Social Studies - IJONASS" is licensed under a Creative Commons Attribution-NonCommercial-ShareAlike 4.0 International License. 